\title{
Entrepreneurship Development among Nigerian Youths; Empirical Identification of the Driven Factors
}

\author{
Dada Matthew Abiodun ${ }^{1, *}$, Fayomi Olugbenga Abimbola ${ }^{2}$, Simeon-Fayomi Bolanle Clara ${ }^{3}$ \\ ${ }^{1}$ Department of Economics, Faculty of social and Management Sciences Wellspring University, Benin City, Nigeria \\ ${ }^{2}$ Centre for entrepreneurship and Development Studies, Obafemi Awolowo University, Ile-Ife Nigeria \\ ${ }^{3}$ Department of Adult Education, Faculty of Education, Obafemi Awolowo University, Ile-Ife Nigeria
}

Email address:

Mattabey@yahoo.com (D. M. Abiodun)

\section{To cite this article:}

Dada Matthew Abiodun, Fayomi Olugbenga Abimbola, Simeon-Fayomi Bolanle Clara. Entrepreneurship Development among Nigerian Youths, Empirical Identification of the Driven Factors. International Journal of Business and Economics Research.

Vol. 3, No. 6, 2014, pp. 250-258. doi: 10.11648/j.ijber.20140306.16

\begin{abstract}
This study empirically identified the driven factors into entrepreneurship among Nigerian youths with a view to isolating those factors that are fundamental to youths' entrepreneurship development in Nigeria. The study employed a survey design. Data were collected on socio-economic and demographic characteristics as well as personal entrepreneurial competencies of the sampled students from the selected three out of the nation's tertiary institutions. Structured questionnaire was designed and used as instrument of data collection. The reliability of the instrument was established at ( $\mathrm{r}=0.754)$. The validity of the instrument was also scrutinized by experts before finally used. The data collected were analyzed using inferential statistics. The result showed that age significantly influenced proactiveness and goal setting while marital status significantly influenced demand for efficiency and quality. Also, exposure to enterprise education/training influenced opportunity seeking, father's occupation significantly influenced information seeking, and cumulative grade point average significantly influenced information seeking and independence and self confidence. The course of study significantly influenced risk taking propensity, persuasion and networking, and independence and self-confidence. The area of discipline significantly influenced risk taking propensity while perception of parents' entrepreneurial success significantly influenced information seeking, risk taking propensity, proactiveness and goal setting and persuasion and networking. On the contrary, mother's occupation, monthly allowance received, parents' financial status, position among siblings, where one spent his or her childhood days, ethnic group belonging were found to have no significant influence on personal entrepreneurial competencies of the respondents. Policy strategy on entrepreneurship development should take cognizance of factors which significantly influenced entrepreneurial resourcefulness of the Nigerian youths in order to enhance enterprise culture and check unemployment rate and its consequences in Nigeria. The study concluded that socio-economic and demographic variables are vital for consideration in nourishing and nurturing entrepreneurial spirit in Nigeria.
\end{abstract}

Keywords: Socio-Economic Factors, Demographic Factors, Entrepreneurship Development, Nigerian Youth, Driven Factors

\section{Introduction}

The alarming rate of unemployment and its social consequences among Nigerian youths in recent time has become an issue of concern to all stakeholders and even mere observers. Although, this trend is not limited to Nigeria alone, it cuts across the globe. However, the seriousness of this problem varies across countries and regions and hence attention given to tackle the problem also varies as well. A common solution to unemployment problem cut across the world is "through the encouragement of "entrepreneurship and small business creation. From the trend of events in present day Nigeria, it could be seen that Nigerian economy is under-performing despite the various measures put in place by the government It could be recalled that government in recent time has done so much to improve the overall quality of lives of all and sundry through a lot of her empowerment programmes such as skills acquisition through training and re-training programmes, provision of socio-security funds for unemployed and ageing citizens, scholarship awards and bursary disburstment. Following the presidential initiative to introduce entrepreneurship education in all tertiary institutions commencing from the academic year 2007/2008, 
the secretariat of the National Universities Commission NUC held a meeting on 28 September 2006 with development/donor partners and formulated a resolution on the establishment of entrepreneurship centres in Nigerian Universities. The central message of this resolution is that the National Universities Commission in consonance with the Federal Government of Nigeria should enhance the employability and self employment potential of Nigerian graduate students. This led to the introduction of entrepreneurship education as a mandatory course for all Nigerian undergraduate students.

To top it all, government provided both financial and logistic supports to entrepreneurship education in all the nation's tertiary institutions. This is with a view to imbibing the spirit of entrepreneurship in the Nigerian graduate students. Given the high investment of resources in entrepreneurship education, a general consensus emerges in the literature that the primary aim of this programme is the promotion of the successful formation of new ventures (Curran and Stanworth, 1989). Supporting this assertion, McMullan and Long (1987) argued that unlike other university degrees, the success of entrepreneurship programme cannot be evaluated by the number of students graduated but more appropriately measured by an appreciable increase in the number of graduate students with positive attitude towards entrepreneurship and the number of new businesses being added to the existing ones on yearly basis as well as success rate. Issues such as the number of companies created, the number of additional jobs created, the types of companies formed, and the growth potential of such companies are essential for economic growth (Wennekers and Sternberg, 2005; Wong et al., 2005). However, it is very unfortunate that there is little or nothing on ground to justify the input so far. The number of unemployed graduates has continued to rise each year likewise the poverty rate. This indicates that government has made little or no impact on the people especially on this subject matter. The reason for this could be traced to the growing level of corruption among the bureaucrat who always acts as the machinery through which the government reaches the masses. Another reason is the problem of mis-match between actions taken and actions required. This is similar to the problem confronting our educational system. A situation in which there is a mis-match between imparted skills and job required skills leading to problem of unemployability among the graduate students in the labour market. Given this background, the introduction of entrepreneurship education may not achieve much without having first identified the driven factors and institute a policy towards nourishing and nurturing of those factors that would make entrepreurship education more result-oriented and an effective tool to combat unemployment problem in Nigeria. There has been an increasing interest in entrepreneurship development as a way out of poverty and unemployment problem. Due to the prevailing economic conditions, policy makers across the globe have in the recent time consented to recognize entrepreneurship as instrument for economic emancipation. According to Acs et al.,(1999) and Bruyat and
Julien (2000), new and growing businesses are seen as a solution to increasing wave of unemployment, and as a major catalyst to national economic prosperity. This fact has led to entrepreneurship policy formulation and implementation in order to foster entrepreneurship development among Nigerian youths. On this note this study is set to empirically identify the socio-economic and demographic characteristics that significantly influenced entrepreneurial skillfulness among the youths which are vital for consideration in an attempt to nourishing and nurturing entrepreneurial spirit in Nigeria. The rest of this paper is organized as follows; section two gives a brief literature review on this subject matter, section three describes the methodology employed, section four discusses the empirical findings while section five concludes.

\section{Literature Review}

The number of entrepreneurs in the total population of a country matters for economic prosperity of such a country. In this regards, this review begins by exploring different views on who an entrepreneur is. According to business scholars, entrepreneur has been described in the following manner: a person who assumes the risk associated with uncertainty (Cantillon, Say, Jean-Baptiste), an innovator (Schumpeter, Drucker), a decision maker (Cantillon, Say, Casson), an industrial leader (Schumpeter), a manager or superintendent (Say, Menger)., an organizer or coordinator (Schumpeter, Leibenstein, Casson), a proprietor of enterprise (Casson), an employer of factors of production (Say, Menger), an arbitrager (Cantillon, Leibenstein) and a supplier of financial capital (Leibenstein). All these views are justified considering the differing roles of an entrepreneur in an economy.

Morris (1997) defines entrepreneurship as the process through which individuals and/or teams create value by bringing together unique packages of resource inputs to exploit opportunities in the environment. Prior research suggests identifying and nurturing potential entrepreneurs throughout the education process could produce many longterm economic benefits (Hansemark, 2003). A study conducted by Parker (2005) stressed the importance of education and training for existing entrepreneurs as it was found that entrepreneurs learned rather slowly and they tend to rely disproportionately on prior beliefs and past experiences. Rae and Carswell (2001) and Shepherd and Douglas (1997) argued that there is a distinction between the teachable and the non teachable elements of entrepreneurship.

Saks and Gaglio (2002) asserted that while it is possible to teach participants of entrepreneurship programmes to evaluate opportunities, the innate ability to recognize opportunities remains virtually non-teachable.

Rasheed (2002) argues that the literature on entrepreneurial characteristics included a number of variables that address the attributes, personality, attitudes and behaviour of the entrepreneur. He posited that some of these variables are loosely coupled elements of the individual but 
necessarily interchangeable. However, he suggested that to avoid a lengthy theoretical discussion, the various research studies in the literature groups them generically as personal entrepreneurial characteristics (PEC).

\section{Methodology}

The study employed a survey research design. A survey consists of collecting data on a large number of people using a representative sample of them. We used multi-stage and purposive sampling techniques to select 1040 students altogether from the three selected universities namely Obafemi Awolowo university, Ile-Ife representing all federal tertiary institutions, Lagos state university, Ojo representing all state tertiary institutions and Covenant university, Otta representing all private tertiary institutions in Nigeria.

Primary data were sourced on socio-economic and demographic characteristics as well as personal entrepreneurial competencies of selected students from these institutions. Structured questionnaire was designed and used as instrument of data collection. The instrument was tested and confirmed for reliability and validity. The coefficient of reliability was obtained as $(r=0.754)$. The validity of the instrument was scrutinized by the experts in the field. The data collected were analyzed using inferential statistics.

\section{Empirical Findings}

\subsection{Results of one Way ANOVA Comparing PEC of Students across Area of Discipline}

Table 1. Results of one way ANOVA comparing students' PEC across area of discipline.

\begin{tabular}{|c|c|c|c|c|}
\hline Variable & $\mathbf{d} / \mathbf{f}$ & F-value & P-value & Decision rule \\
\hline Opportunity seeking & $3 / 786$ & 0.942 & 0.420 & Do not Reject H0 \\
\hline Persistence & $3 / 786$ & 0.095 & 0.963 & Do not Reject H0 \\
\hline Commitment to the work contract & $3 / 786$ & 1.455 & 0.225 & Do not Reject H0 \\
\hline Demand for efficiency and quality & $3 / 786$ & 0.160 & 0.923 & Do not Reject H0 \\
\hline Risk taking propensity & $3 / 786$ & 3.759 & 0.011 & Reject H0 5\% \\
\hline Proactiveness and goal setting & $3 / 786$ & 1.909 & 0.127 & Do not Reject H0 \\
\hline Information seeking & $3 / 786$ & 0.347 & 0.791 & Do not Reject H0 \\
\hline Persuasion and networking & $3 / 786$ & 2.050 & 0.105 & Do not Reject H0 \\
\hline Independence and self-confidence & $3 / 786$ & 1.091 & 0.352 & Do not Reject H0 \\
\hline PEC index & $3 / 786$ & 0.552 & 0.647 & Do not Reject H0 \\
\hline
\end{tabular}

Source: Field Survey, 2013

The study used one way ANOVA to find out if there is significant difference in the personal entrepreneurial competencies of students across area of discipline, the results showed that significant difference exists only on risk taking propensity ( $\mathrm{F}=3.759$; $\mathrm{df}=3 / 786 ; \mathrm{P}<0.05)$. This showed that risk taking propensity differ significantly across area of discipline. By this result, it is revealed that area of discipline significantly influence risk taking propensity. This results need a serious consideration for policy debates as per motivation of student into discipline that encourage youths to take risk since entrepreneurship itself is an embodiment of risk taking. It is empirically sound that a society with many risk aversion youths would suffer low rate of entrepreneurship leading to low rate of economic growth, worsening unemployment condition and vicious circle of poverty.

\subsection{Results of One Way ANOVA Comparing Students'PEC Across Course of Study}

Table 2. Results of one way ANOVA comparing students' PEC across course of study.

\begin{tabular}{|c|c|c|c|c|}
\hline Variable & $\mathbf{d} / \mathbf{f}$ & F-value & P-value & Decision rule \\
\hline Opportunity seeking & $10 / 779$ & 1.632 & 0.093 & Do not Reject H0 \\
\hline Persistence & $10 / 779$ & 1.334 & 0.208 & Do not Reject H0 \\
\hline Commitment to the work contract & $10 / 779$ & 0.911 & 0.523 & Do not Reject H0 \\
\hline Demand for efficiency and quality & $10 / 779$ & 1.486 & 0.140 & Do not Reject H0 \\
\hline Risk taking propensity & $10 / 779$ & 2.503 & 0.006 & Reject H0 5\% \\
\hline Proactiveness and goal setting & $10 / 779$ & 1.577 & 0.109 & Do not Reject H0 \\
\hline Systematic planning and monitoring & $10 / 779$ & 1.047 & 0.402 & Do not Reject H0 \\
\hline Persuasion and networking & $10 / 779$ & 1.844 & 0.050 & Reject H0 5\% \\
\hline Independence and self-confidence & $10 / 779$ & 2.307 & 0.011 & Reject $\mathrm{H} 05 \% \mathrm{H} 0$ \\
\hline PEC index & $10 / 779$ & 1.558 & 0.115 & Do not Reject H0 \\
\hline
\end{tabular}

Source: Field Survey, 2013

The study employed one way ANOVA to compare students' personal entrepreneurial competencies across course of study, the results showed that significant difference exists in risk taking propensity $(\mathrm{F}=2.503 ; \mathrm{df}=10 / 779 ; \mathrm{P}<0.01)$; and 
independence and self-confidence $(\mathrm{F}=2.307$; df $=10 / 779$; $\mathrm{P}<0.05)$. This implied that risk taking propensity as well as independence and self-confidence differ significantly across course of study. By this result, it is revealed that course of study significantly influenced risk taking propensity as well as independence and self-confidence. This result needs to be given a serious consideration for policy debates as per motivation of students into courses that encourage youths to take risk as well as having strong desire to be independent and self-confident since entrepreneurship itself is an embodiment of risk and strong determination to be independent and self-confident. It is empirically sound that a society with many risk aversion youths with little or no regards for being independent and self-confident would suffer low rate of entrepreneurship leading to low rate of economic growth, worsening unemployment condition and vicious circle of poverty which in turn has strong implication for crime rate and social unrest in the society.

\subsection{Results of One Way ANOVA Comparing Students'PEC across Institutions}

In an attempt to know if differences exist in PEC across institutions, we adopted one way ANOVA. The results showed that a significant difference exist in opportunity seeking $(\mathrm{F}=8.033 ; \mathrm{df}=2 / 787 ; \mathrm{P}<0.01)$. This implies that institutional variation significantly influenced entrepreneurial capability of the respondents.

Table 3. Results of one way ANOVA comparing students'PEC across institutions.

\begin{tabular}{|c|c|c|c|c|}
\hline Variable & $\mathbf{d} / \mathbf{f}$ & F-value & P-value & Decision rule \\
\hline Opportunity seeking & $2 / 787$ & 8.033 & 0.000 & Reject $\mathrm{H} 0$ at $1 \%$ \\
\hline Persistence & $2 / 787$ & 2.486 & 0.084 & Do not Reject H0 \\
\hline Commitment to the work contract & $2 / 787$ & 0.389 & 0.678 & Do not Reject H0 \\
\hline Demand for efficiency and quality & $2 / 787$ & 1.902 & 0.150 & Do not Reject H0 \\
\hline Risk taking propensity & $2 / 787$ & 1.271 & 0.104 & Do not Reject H0 \\
\hline Information seeking & $2 / 787$ & 1.220 & 0.296 & Do not Reject H0 \\
\hline Systematic planning and monitoring & $2 / 787$ & 0.918 & 0.400 & Do not Reject H0 \\
\hline Persuasion and networking & $2 / 787$ & 1.680 & 0.187 & Do not Reject H0 \\
\hline Independence and self-confidence & $2 / 787$ & 0.643 & 0.526 & Do not Reject H0 \\
\hline PEC index & $2 / 787$ & 2.062 & 0.128 & Do not Reject H0 \\
\hline
\end{tabular}

Source: Field Survey, 2013

\subsection{Results of One Way ANOVA Comparing Students' PEC across CGPA}

In order to find out if there is significant difference in personal entrepreneurial competencies of those students in first class, second class upper division, second class lower division, third class and those in the ordinary pass grade category, the study conducted a one way ANOVA, the results showed that significant difference exist in information seeking $\quad(\mathrm{F}=2.799 ; \quad \mathrm{df}=3 / 786 ; \quad \mathrm{P}<0.05) \quad$ as $\quad$ well as independence and self confidence $(\mathrm{F}=3.900$; $\mathrm{df}=3 / 786$; $\mathrm{P}<$ $0.01)$.

Table 4. Results of One Way ANOVA Comparing Students' PEC across CGPA

\begin{tabular}{|c|c|c|c|c|}
\hline Variable & $\mathrm{d} / \mathrm{f}$ & F-value & P-value & Decision rule \\
\hline Opportunity seeking & $3 / 786$ & 1.995 & 0.113 & Do not Reject H0 \\
\hline Persistence & $3 / 786$ & 0.713 & 0.544 & Do not Reject H0 \\
\hline Commitment to the work contract & $3 / 786$ & 2.574 & 0.053 & Do not Reject H0 \\
\hline Demand for efficiency and quality & $3 / 786$ & 1.736 & 0.158 & Do not Reject H0 \\
\hline Risk taking propensity & $3 / 786$ & 1.890 & 0.130 & Do not Reject H0 \\
\hline Proactiveness and goal setting & $3 / 786$ & 1.130 & 0.336 & Do not Reject H0 \\
\hline Information seeking & $3 / 786$ & 2.799 & 0.039 & Reject $\mathrm{H} 0$ at $5 \%$ \\
\hline Persuasion and networking & $3 / 786$ & 0.580 & 0.628 & Do not Reject H0 \\
\hline Independence and self-confidence & $3 / 786$ & 3.900 & 0.009 & Reject $\mathrm{H} 0$ at $1 \%$ \\
\hline PEC index & $3 / 786$ & 1.997 & 0.113 & Do not Reject H0 \\
\hline
\end{tabular}

Source: Field Survey, 2013

\subsection{Results of One Way ANOVA Comparing Students'PEC across Father's Occupation}

To find out if father's occupation have any significant influence on the personal entrepreneurial competencies of the study respondents, the study conducted a one way ANOVA, the results showed that father's occupation have significant influence on information seeking ( $\mathrm{F}=3.224$; $\mathrm{df}=2 / 787$; $\mathrm{P}<$ 0.05). Respondent father's occupation significantly influenced respondents' ability to seek business information. 
Table 5. Results of one way ANOVA comparing students' PEC across father's occupation.

\begin{tabular}{|c|c|c|c|c|}
\hline Variable & $\mathbf{d} / \mathbf{f}$ & F-value & P-value & Decision rule \\
\hline Opportunity seeking & $2 / 787$ & 0.876 & 0.417 & Do not Reject H0 \\
\hline Persistence & $2 / 787$ & 1.642 & 0.194 & Do not Reject H0 \\
\hline Commitment to the work contract & $2 / 787$ & 0.184 & 0.832 & Do not Reject H0 \\
\hline Demand for efficiency and quality & $2 / 787$ & 1.778 & 0.170 & Do not Reject H0 \\
\hline Risk taking propensity & $2 / 787$ & 0.233 & 0.792 & Do not Reject H0 \\
\hline Proactiveness and goal setting & $2 / 787$ & 2.074 & 0.126 & Do not Reject H0 \\
\hline Information seeking & $2 / 787$ & 3.224 & 0.040 & Reject $\mathrm{H} 0$ at $5 \%$ \\
\hline Persuasion and networking & $2 / 787$ & 2.687 & 0.069 & Do not Reject H0 \\
\hline Independence and self-confidence & $2 / 787$ & 1.391 & 0.249 & Reject $\mathrm{H} 0$ at $1 \%$ \\
\hline PEC index & $2 / 787$ & 1.807 & 0.165 & Do not Reject H0 \\
\hline
\end{tabular}

Source: Field Survey, 2013

\subsection{Results of One Way ANOVA Comparing Students' PEC across Mother'S Occupation}

To find out if mother's occupation have any significant influence on the personal entrepreneurial competencies of the study respondents, the study conducted a one way ANOVA, the results showed that mother's occupation have no significant influence on entrepreneurial resourcefulness of the respondents. This result indicates that mother's occupation have no significant influence on the entrepreneurial skillfulness of the study sample.

Table 6. Results of one way ANOVA comparing students' PEC across mother's occupation.

\begin{tabular}{|c|c|c|c|c|}
\hline Variable & $\mathbf{d} / \mathbf{f}$ & F-value & P-value & Decision rule \\
\hline Opportunity seeking & $2 / 787$ & 0.243 & 0.784 & Do not Reject H0 \\
\hline Persistence & $2 / 787$ & 0.035 & 0.965 & Do not Reject H0 \\
\hline Commitment to the work contract & $2 / 787$ & 0.373 & 0.689 & Do not Reject H0 \\
\hline Risk taking propensity & $2 / 787$ & 0.607 & 0.545 & Do not Reject H0 \\
\hline Proactiveness and goal setting & $2 / 787$ & 0.251 & 0.778 & Do not Reject H0 \\
\hline Information seeking & $2 / 787$ & 0.129 & 0.879 & Reject $\mathrm{H} 0$ at $5 \%$ \\
\hline Persuasion and networking & $2 / 787$ & 0.352 & 0.704 & Do not Reject H0 \\
\hline Independence and self-confidence & $2 / 787$ & 1.504 & 0.223 & Do not Reject H0 \\
\hline PEC index & $2 / 787$ & 0.000 & 1.000 & Do not Reject H0 \\
\hline
\end{tabular}

Source: Field Survey, 2013

\subsection{Results of One Way ANOVA Comparing Students' PEC across Age}

To find out if age has any significant influence on the personal entrepreneurial competencies of the study respondents, the study conducted a one way ANOVA, the results showed that age significantly influenced proactiveness and goal setting $(\mathrm{F}=3.814 ; \mathrm{d} / \mathrm{f}=3 / 786 ; \mathrm{p}<0.05)$.

Table 7. Results of one way ANOVA comparing students' PEC across age

\begin{tabular}{|c|c|c|c|c|}
\hline Variable & $\mathbf{d} / \mathbf{f}$ & F-value & P-value & Decision rule \\
\hline Opportunity seeking & $3 / 786$ & 0.432 & 0.730 & Do not Reject H0 \\
\hline Persistence & $3 / 786$ & 0.292 & 0.831 & Do not Reject H0 \\
\hline Commitment to the work contract & $3 / 786$ & 1.325 & 0.265 & Do not Reject H0 \\
\hline Demand for efficiency and quality & $3 / 786$ & 1.100 & 0.349 & Do not Reject H0 \\
\hline Risk taking propensity & $3 / 786$ & 1.348 & 0.258 & Do not Reject H0 \\
\hline Proactiveness and goal setting & $3 / 786$ & 3.814 & 0.010 & Reject $\mathrm{H} 0$ at $1 \%$ \\
\hline Information seeking & $3 / 786$ & 1.222 & 0.301 & Do not Reject H0 \\
\hline Persuasion and networking & $3 / 786$ & 0.295 & 0.829 & Do not Reject H0 \\
\hline Independence and self-confidence & $3 / 786$ & 0.634 & 0.593 & Do not Reject H0 \\
\hline PEC index & $3 / 786$ & 1.091 & 0.352 & Do not Reject H0 \\
\hline
\end{tabular}

Source: Field Survey, 2013

\subsection{Results of One Way ANOVA Comparing PEC across Ethnic Group}

To find out if ethnic group belonging has any significant influence on the personal entrepreneurial competencies of the study respondents, the study conducted a one way ANOVA, the results showed that there is no significant difference in PEC performance of different ethnic group $(\mathrm{F}=1.209 ; \mathrm{d} / \mathrm{f}=3 / 786$; 
$\mathrm{p}>0.05$ ). This result indicates that the ethnic group a respondent

belongs has no significant influence on their PECs

Table 8. Results of one way ANOVA comparing students'PEC across ethnic group

\begin{tabular}{|c|c|c|c|c|}
\hline Variable & $\mathbf{d} / \mathbf{f}$ & F-value & P-value & Decision rule \\
\hline Opportunity seeking & $3 / 786$ & 1.393 & 0.244 & Do not Reject H0 \\
\hline Persistence & $3 / 786$ & 1.124 & 0.339 & Do not Reject $\mathrm{H} 0$ \\
\hline Commitment to the work contract & $3 / 786$ & 1.023 & 0.382 & Do not Reject H0 \\
\hline Demand for efficiency and quality & $3 / 786$ & 0.935 & 0.423 & Do not Reject H0 \\
\hline Risk taking propensity & $3 / 786$ & 1.389 & 0.245 & Do not Reject H0 \\
\hline Proactiveness and goal setting & $3 / 786$ & 1.354 & 0.258 & Reject $\mathrm{H} 0$ at $1 \%$ \\
\hline Information seeking & $3 / 786$ & 0.857 & 0.463 & Do not Reject H0 \\
\hline Persuasion and networking & $3 / 786$ & 2.160 & 0.091 & Do not Reject H0 \\
\hline Independence and self-confidence & $3 / 786$ & 0.465 & 0.707 & Do not Reject H0 \\
\hline PEC index & $3 / 786$ & 1.209 & 0.306 & Do not Reject H0 \\
\hline
\end{tabular}

Source: Field Survey, 2013

\subsection{Results of One Way ANOVA Comparing Students' PEC across Monthly Allowance Received}

The respondents differ in the monthly allowance they receive from parents/guardians. To find out if this differing factor would have any significant influence on their personal entrepreneurial competencies, the study conducted a one way
ANOVA, the results showed that there is no significant difference in PEC performance across monthly allowance received $(\mathrm{F}=0.655 ; \mathrm{d} / \mathrm{f}=3 / 786 ; \mathrm{p}>0.05)$. This result indicates that monthly allowance received by the respondents does not have any significant influence on their PECs.

Table 9. Results of one way ANOVA comparing students' PEC across monthly allowance received

\begin{tabular}{|c|c|c|c|c|}
\hline Variable & $\mathbf{d} / \mathbf{f}$ & F-value & P-value & Decision rule \\
\hline Opportunity seeking & $3 / 786$ & 0.592 & 0.620 & Do not Reject H0 \\
\hline Persistence & $3 / 786$ & 0.472 & 0.702 & Do not Reject H0 \\
\hline Commitment to the work contract & $3 / 786$ & 0.828 & 0.479 & Do not Reject H0 \\
\hline Risk taking propensity & $3 / 786$ & 0.041 & 0.989 & Do not Reject H0 \\
\hline Proactiveness and goal setting & $3 / 786$ & 1.015 & 0.385 & Do not Reject H0 \\
\hline Information seeking & $3 / 786$ & 0.183 & 0.908 & Do not Reject H0 \\
\hline Persuasion and networking & $3 / 786$ & 1.751 & 0.155 & Do not Reject H0 \\
\hline Independence and self-confidence & $3 / 786$ & 0.681 & 0.564 & Do not Reject H0 \\
\hline PEC index & $3 / 786$ & 0.655 & 0.580 & Do not Reject H0 \\
\hline
\end{tabular}

Source: Field Survey, 2013

\subsection{Results of One Way ANOVA Comparing Students' PEC across Parents' Financial Status}

Parents' financial status differs across the study sample, in order to find out if this could significantly influence their PECs, the study conducted a one way ANOVA, the results showed that there is no significant difference in PECs across parents' financial status $(\mathrm{F}=0.484 ; \mathrm{d} / \mathrm{f}=3 / 786 ; \mathrm{p}>0.05)$. This result indicates that parents' financial status has no significant influence on PECs.

Table 10. Results of one way ANOVA comparing students' PEC across parents' financial status

\begin{tabular}{|c|c|c|c|c|}
\hline Variable & $\mathbf{d} / \mathbf{f}$ & F-value & P-value & Decision rule \\
\hline Opportunity seeking & $3 / 786$ & 0.725 & 0.537 & Do not Reject H0 \\
\hline Persistence & $3 / 786$ & 0.524 & 0.666 & Do not Reject H0 \\
\hline Commitment to the work contract & $3 / 786$ & 0.321 & 0.810 & Do not Reject H0 \\
\hline Demand for efficiency and quality & $3 / 786$ & 0.291 & 0.832 & Do not Reject H0 \\
\hline Risk taking propensity & $3 / 786$ & 0.781 & 0.505 & Do not Reject H0 \\
\hline Proactiveness and goal setting & $3 / 786$ & 0.317 & 0.813 & Do not Reject H0 \\
\hline Systematic planning and monitoring & $3 / 786$ & 0.872 & 0.455 & Do not Reject H0 \\
\hline Persuasion and networking & $3 / 786$ & 0.573 & 0.633 & Do not Reject H0 \\
\hline Independence and self-confidence & $3 / 786$ & 1.268 & 0.284 & Do not Reject H0 \\
\hline PEC index & $3 / 786$ & 0.484 & 0.693 & Do not Reject H0 \\
\hline
\end{tabular}

Source: Field Survey, 2013 


\subsection{Results of One Way ANOVA Comparing Students' PEC across Respondent's Position among Siblings}

Position among siblings is one of the explanatory variables in this study since respondents vary in their position among siblings. To find out if position among siblings has any significant influence on the personal entrepreneurial competencies of the study respondents, the study conducted a one way ANOVA, the results showed that there is no significant difference in PECs across position among siblings $(\mathrm{F}=1.329 ; \mathrm{d} / \mathrm{f}=5 / 784 ; \mathrm{p}>0.05)$. This result indicates that position among siblings has no significant influence on PECs.

Table 11. Results of one way ANOVA comparing students' PEC across respondent's position among siblings

\begin{tabular}{|c|c|c|c|c|}
\hline Variable & $\mathbf{d} / \mathbf{f}$ & F-value & P-value & Decision rule \\
\hline Opportunity seeking & $5 / 784$ & 2.042 & 0.071 & Do not Reject H0 \\
\hline Persistence & $5 / 784$ & 0.876 & 0.496 & Do not Reject H0 \\
\hline Commitment to the work contract & $5 / 784$ & 0.642 & 0.668 & Do not Reject H0 \\
\hline Demand for efficiency and quality & $5 / 784$ & 1.334 & 0.248 & Do not Reject H0 \\
\hline Risk taking propensity & $5 / 784$ & 1.843 & 0.102 & Do not Reject H0 \\
\hline Proactiveness and goal setting & $5 / 784$ & 1.334 & 0.248 & Do not Reject H0 \\
\hline Information seeking & $5 / 784$ & 1.616 & 0.153 & Do not Reject H0 \\
\hline Persuasion and networking & $5 / 784$ & 0.800 & 0.550 & Do not Reject H0 \\
\hline Independence and self-confidence & $5 / 784$ & 1.784 & 0.114 & Do not Reject H0 \\
\hline PEC index & $5 / 784$ & 1.329 & 0.250 & Do not Reject H0 \\
\hline
\end{tabular}

Source: Field Survey, 2013

\subsection{Results of One Way ANOVA Comparing Students' PEC across where One Spent His/Her Childhood Days}

To find out if where one spent his/her childhood days has any significant influence on the personal entrepreneurial competencies, the study collected data on where one spent his or her childhood days and later conducted a one way ANOVA to compare PECs, the results showed that there is significant difference on persistence $(\mathrm{F}=3.387 ; \mathrm{d} / \mathrm{f}=3 / 786$; $\mathrm{p}<0.05)$. This result indicates that where one spent his/her childhood days has significant influence only on persistence.

Table 12. Results of one way ANOVA comparing students'PEC across where one spent his/her childhood days

\begin{tabular}{|c|c|c|c|c|}
\hline Variable & $\mathrm{d} / \mathrm{f}$ & F-value & P-value & Decision rule \\
\hline Opportunity seeking & $3 / 786$ & 1.073 & 0.360 & Do not Reject H0 \\
\hline Persistence & $3 / 786$ & 3.387 & 0.018 & Reject $\mathrm{H} 0$ at $5 \%$ \\
\hline Commitment to the work contract & $3 / 786$ & 0.606 & 0.611 & Do not Reject H0 \\
\hline Demand for efficiency and quality & $3 / 786$ & 0.573 & 0.633 & Do not Reject H0 \\
\hline Risk taking propensity & $3 / 786$ & 0.350 & 0.789 & Do not Reject H0 \\
\hline Proactiveness and goal setting & $3 / 786$ & 0.712 & 0.545 & Do not Reject H0 \\
\hline Information seeking & $3 / 786$ & 1.344 & 0.259 & Do not Reject H0 \\
\hline Persuasion and networking & $3 / 786$ & 0.470 & 0.703 & Do not Reject H0 \\
\hline Independence and self-confidence & $3 / 786$ & 2.024 & 0.109 & Do not Reject H0 \\
\hline PEC index & $3 / 786$ & 1.574 & 0.194 & Do not Reject H0 \\
\hline
\end{tabular}

Source: Field Survey, 2013

\subsection{Results of One Way ANOVA Comparing Students' PEC across Religion}

Table 13. Results of one way ANOVA comparing students' PEC across religion

\begin{tabular}{|c|c|c|c|c|}
\hline Variable & $\mathbf{d} / \mathbf{f}$ & F-value & P-value & Decision rule \\
\hline Opportunity seeking & $3 / 786$ & 4.501 & 0.005 & Reject $\mathrm{H} 0$ at $1 \%$ \\
\hline Persistence & $3 / 786$ & 6.869 & 0.000 & Reject $\mathrm{H} 0$ at $1 \%$ \\
\hline Commitment to the work contract & $3 / 786$ & 5.281 & 0.001 & Reject $\mathrm{H} 0$ at $1 \%$ \\
\hline Demand for efficiency and quality & $3 / 786$ & 1.819 & 0.142 & Do not Reject H0 \\
\hline Risk taking propensity & $3 / 786$ & 0.840 & 0.472 & Do not Reject H0 \\
\hline Proactiveness and goal setting & $3 / 786$ & 1.533 & 0.205 & Do not Reject H0 \\
\hline Information seeking & $3 / 786$ & 2.786 & 0.040 & Reject $\mathrm{H} 0$ at $5 \%$ \\
\hline Persuasion and networking & $3 / 786$ & 7.137 & 0.000 & Reject $\mathrm{H} 0$ at $1 \%$ \\
\hline Independence and self-confidence & $3 / 786$ & 3.218 & 0.022 & Reject $\mathrm{H} 0$ at $5 \%$ \\
\hline PEC index & $3 / 786$ & 4.377 & 0.005 & Reject $\mathrm{H} 0$ at $1 \%$ \\
\hline
\end{tabular}


In order to find out if there exist a significant difference in the personal entrepreneurial competencies of the study sampled across religion, the study conducted a one way ANOVA, the results showed that significant difference exist in information seeking ( $\mathrm{F}=2.786$; df $=3 / 786 ; \mathrm{P}<0.05)$; Persistence ( $\mathrm{F}=6.869$, df $=3 / 786 ; \mathrm{P}<0.01)$, Commitment to the work contract $(\mathrm{F}=5.281 ; \mathrm{df}=3 / 786 ; \mathrm{P}<0.01)$, Opportunity seeking $(\mathrm{F}=4.501 ;$ df $=3 / 786 ; \mathrm{P}<0.01)$, Persuasion and networking $(\mathrm{F}=7.132 ; \mathrm{df}=3 / 786 ; \mathrm{P}<0.01)$, Independence and self-confidence $(\mathrm{F}=3.218$; df $=3 / 786 ; \mathrm{P}<0.05)$, PEC index ( $F=4.377$; df $=3 / 786 ; \mathrm{P}<0.01$ ). Religion was found to have significant influence on PECs.

\subsection{Results of One Way ANOVA Comparing Students' PEC across Perception of Parents' Entrepreneurial Success}

Table 14. Results of one way ANOVA comparing students' PEC across perception of parents 'entrepreneurial success

\begin{tabular}{|c|c|c|c|c|}
\hline Variable & $\mathbf{d} / \mathbf{f}$ & F-value & P-value & Decision rule \\
\hline Opportunity seeking & $3 / 786$ & 2.215 & 0.085 & Do not Reject H0 \\
\hline Persistence & $3 / 786$ & 2.391 & 0.067 & Reject $\mathrm{H} 0$ at $1 \%$ \\
\hline Commitment to the work contract & $3 / 786$ & 2.287 & 0.077 & Do not Reject H0 \\
\hline Risk taking propensity & $3 / 786$ & 3.781 & 0.010 & Reject $\mathrm{H} 0$ at $1 \%$ \\
\hline Proactiveness and goal setting & $3 / 786$ & 4.431 & 0.004 & Reject $\mathrm{H} 0$ at $1 \%$ \\
\hline Information seeking & $3 / 786$ & 5.190 & 0.001 & Reject $\mathrm{H} 0$ at $1 \%$ \\
\hline Persuasion and networking & $3 / 786$ & 4.913 & 0.002 & Reject $\mathrm{H} 0$ at $1 \%$ \\
\hline Independence and self-confidence & $3 / 786$ & 2.430 & 0.064 & Do not Reject H0 \\
\hline PEC index & $3 / 786$ & 4.452 & 0.004 & Reject $\mathrm{H} 0$ at $1 \%$ \\
\hline
\end{tabular}

Source: Field Survey, 2013

In order to find out if there is a significant difference in the personal entrepreneurial competencies of the study sample across different perception of parents' entrepreneurial success, the study conducted a one way ANOVA, the results showed that there is significant difference in information seeking ( $\mathrm{F}=5.190 ; \mathrm{df}=3 / 786 ; \mathrm{P}<0.01$ ); Risk taking propensity $(\mathrm{F}=3.781, \mathrm{df}=3 / 786 ; \mathrm{P}<0.05)$, Proactiveness and goal setting $(\mathrm{F}=4.431 ; \mathrm{df}=3 / 786 ; \mathrm{P}<0.01)$, Persuasion and networking $(\mathrm{F}=4.913 ; \mathrm{df}=3 / 786 ; \mathrm{P}<0.01)$. In all, students' perception of parents' entrepreneurial success significantly influenced PECs.

\subsection{Results of One Way ANOVA Comparing Students' PECs across Marriage Status}

In order to find out if a significant difference exists in the personal entrepreneurial competencies of the study sample across marriage status, the study conducted a one way ANOVA, the results showed that significant difference exists in Demand for efficiency and quality $(\mathrm{F}=3.478$; $\mathrm{df}=3 / 786$; $\mathrm{P}<0.05)$. This result implies that marriage status significantly influenced demand for efficiency and quality.

Table 15. Results of one way ANOVA comparing students' PEC across marriage status

\begin{tabular}{|c|c|c|c|c|}
\hline & $\mathbf{d} / \mathbf{f}$ & F-value & P-value & Decision rule \\
\hline Opportunity seeking & $3 / 786$ & 0.225 & 0.879 & Do not Reject H0 \\
\hline Persistence & $3 / 786$ & 2.146 & 0.093 & Do not Reject H0 \\
\hline Commitment to the work contract & $3 / 786$ & 0.187 & 0.906 & Do not Reject H0 \\
\hline Demand for efficiency and quality & $3 / 786$ & 3.478 & 0.016 & Reject $\mathrm{H} 0$ at $5 \%$ \\
\hline Risk taking propensity & $3 / 786$ & 0.555 & 0.645 & Do not Reject H0 \\
\hline Proactiveness and goal setting & $3 / 786$ & 1.295 & 0.275 & Do not Reject H0 \\
\hline Information seeking & $3 / 786$ & 1.597 & 0.189 & Do not Reject H0 \\
\hline Persuasion and networking & $3 / 786$ & 1.326 & 0.265 & Do not Reject H0 \\
\hline Independence and self-confidence & $3 / 786$ & 0.317 & 0.813 & Do not Reject H0 \\
\hline PEC index & $3 / 786$ & 0.864 & 0.459 & Do not Reject H0 \\
\hline
\end{tabular}

Source: Field Survey, 2013

\section{Summary, Recommendations and Conclusion}

This study empirically identified the driven factors into entrepreneurship among Nigerian youths with a view to isolate important factors needed to be considered to enhance entrepreneurial and enterprise culture among the youths in Nigeria. Primary data were sourced on socio-economic and demographic characteristics as well as personal entrepreneurial competencies of selected students from the nation's tertiary institutions. Structured questionnaire was designed and used as instrument of data collection. The instrument was tested and confirmed for reliability and validity. The data collected were analyzed using inferential statistics. The result showed that age significantly influenced proactiveness and goal setting; marital status significantly influenced demand for efficiency and quality; exposure to 
enterprise education significantly influenced opportunity seeking; father's occupation significantly influenced information seeking; cumulative grade point average significantly influenced information seeking, independence and self confidence; course of study significantly influenced risk taking propensity, persuasion and networking, independence and self-confidence; area of discipline significantly influenced risk taking propensity; perception of parents' entrepreneurial success significantly influenced information seeking, risk taking propensity, proactiveness and goal setting, persuasion and networking. On the contrary, mother's occupation, monthly allowance received, parents' financial status, position among siblings, where one spent his or her childhood days, ethnic group belonging were found to have no significant influence on personal entrepreneurial competencies of the respondents. Policy strategy on entrepreneurship development in Nigeria should take cognizance of factors which significantly influenced entrepreneurship resourcefulness of the youths and efforts should be geared towards nourishing and nurturing entrepreneurial skillfulness in order to reduce the rate of unemployment among the youths and its accompanied social evils plaguing the society in the recent time. The policy makers are advised to note that for any meaningful development, there is need to expand the level of entrepreneurial activities in the country. The study therefore concluded that socio-economic and demographic variables are vital for consideration in nourishing and nurturing entrepreneurship spirit in Nigeria.

\section{References}

[1] Acs, Z., Carlsson, B., And Karlsson, C., (1999), Entrepreneurship, Small And Medium Enterprises And The Macro-Economy. Cambridge University Press, London.
[2] Bruyat, C. and Julien, P.A., (2000). "Defining the field of research in entrepreneurship". Journal of Business Venturing 16(2): 165-180.

[3] Curran, J. \& Stanworth, J. (1989). Education And Training For Enterprise: Some Problems of Classification, Evaluation, Policy and Research. International Small Business Journal, $7(2)$.

[4] Hansemark, O.C., (2003), Need for Achievement, Locus of Control, and the Prediction of Business Start-Ups: A Longitudinal Study. Journal of Economic Psychology 24(3): 301 .

[5] Leibenstein, H. (1987). Entrepreneurship, entrepreneurial training and $\mathrm{x}$-efficiency theory. Journal of Economic Behaviour and Organization, 8(2), 191-205.

[6] McMullan, W.E. \& Long, W.A. (1983). "An Approach to Educating Entrepreneurs", The Canadian Journal of Business, 4(1), 32-6.

[7] Parker, S.C. (2005). Learning about the unknown: How fast do entrepreneurs adjust their beliefs? Forthcoming in Journal of Business Venturing.

[8] Peterman, N. \& Kennedy J. (2003). "Enterprise Education: Influencing Students' Perceptions Of Entrepreneurship," Entrepreneurship Theory and Practice, 28, 129-144.

[9] Rae, D. \& Carswell, M., (2001). Towards a conceptual understanding of entrepreneurial learning. Journal of Small business and Enterprise Development 8(2): 150-158.

[10] Saks, N.T. and Gaglio, C.M., (2002), Can Opportunity Identification Be Taught? Journal of Enterprising Culture 10(4): 313-347.

[11] Wennekers, S and Sternberg, R. (2005). Determinants and Effects of New Business Creation: Global Entrepreneurship Monitor Data. Small Business Economics 24(3). 193.

[12] Wong, P.K., Ho, Y.P., and Autio, E., (2005), Entrepreneurship, Innovation and Economic Growth: Evidence from GEM data. Small Business Economics 24(3): 335. 